\title{
Phenology of native plants with ornamental potential in Serra do Oratório, Santa Catarina State, Brazil
}

\author{
Fernanda Espíndola Assumpção Bastos ${ }^{1 *}$ (D), Fernanda Grimaldi ${ }^{1}$ (D) \\ ${ }^{1}$ Universidade do Estado de Santa Catarina,Centro de Ciência Agroveterinárias, Departamento de \\ Agronomia, Lages-SC, Brazil.
}

\begin{abstract}
Santa Catarina State is endowed with a flora with great wealth and diversity. The impact that introduction and cultivation of exotic ornamental plants can have on biological diversity is incalculable, and knowledge is of prime importance in measuring this value for the preservation of species and the environment. The objective of this work was to evaluate the phenology of five native species with ornamental potential in the Serra do Oratório, located in the municipality of Bom Jardim da Serra, Santa Catarina State, and to conduct phenological studies of the species Calibrachoa sellowiana (Sendtn.) Wijsman, Baccharis nummularia Heering ex Malme, Trichocline catharinensis Cabrera, Tibouchina dubia (Cham.) Cogn. and Verbena rigida Spreng. Phenological studies occurred between August 2016 and July 2017, with samples of five plants of each species. In this period the occurrence of the phases was recorded: dormancy, vegetation, flower buds or visible inflorescences, full bloom, fruiting and fruit ripening. The esthetic variables evaluated were size, color, texture, line, shape, structure and symmetry of the species. The meteorological variables related to the phenological events were temperature $\left({ }^{\circ} \mathrm{C}\right)$, precipitation $(\mathrm{mm})$ and insolation $(\mathrm{h})$. The species Tibouchina dubia, Verbena rigida and Calibrachoa sellowiana, even with short flowering time, are indicated for use in landscaping in the region of South Catarinense Plateau. The meteorological variables evaluated were correlated with the phenophases of the species studied.
\end{abstract}

Keywords: floriculture, growth phases, native gardening, natural landscaping.

\section{Resumo}

Fenologia de plantas nativas com potencial ornamental na Serra do Oratório - Santa Catarina

O estado de Santa Catarina é dotado de uma flora com grande riqueza e diversidade. O impacto que a introdução e o cultivo de plantas ornamentais exóticas podem causar sobre a diversidade biológica é incalculável, e o conhecimento é primordial para mensurar esse valor para a preservação das espécies e do meio ambiente. O objetivo do presente trabalho foi avaliar a fenologia de cinco espécies nativas com potencial ornamental na Serra do Oratório, localizada no município de Bom Jardim da Serra, em Santa Catarina e realizar estudos fenológicos das espécies Calibrachoa sellowiana (Sendtn.) Wijsman, Baccharis nummularia Heering ex Malme, Trichocline catharinensis Cabrera, Tibouchina dubia (Cham.) Cogn. e Verbena rigida Spreng. Os estudos fenológicos ocorreram entre agosto de 2016 a julho de 2017, com amostras de cinco plantas de cada espécie. Nesse período foi registrada a ocorrência das fases: dormência, vegetação, botões florais ou inflorescências visíveis, plena floração, frutificação e maturação dos frutos. As variáveis estéticas avaliadas foram: porte, cor, textura, linha, forma, estrutura e simetria das espécies. As variáveis meteorológicas relacionadas com os eventos fenológicos foram temperatura $\left({ }^{\circ} \mathrm{C}\right)$, precipitação $(\mathrm{mm})$ e insolação $(\mathrm{h})$. As espécies Tibouchina dubia, Verbena rigida e Calibrachoa sellowiana, mesmo com tempo de floração curto, são indicadas para uso em paisagismo na região do Planalto Sul Catarinense. As variáveis meteorológicas avaliadas apresentaram correlações com as fenofases das espécies estudadas.

Palavras-chave: floricultura, fases de crescimento, jardinagem nativa, paisagismo natural.

\footnotetext{
* Corresponding author: feabastos@hotmail.com
} 


\section{Introduction}

Phenology has recently emerged as an important focus for ecological research, mainly because of its considerable promise to address important issues in global modeling, monitoring and climate change (Schwartz, 1999). The knowledge acquired in phenological studies has important practical implications, providing parameters for conservation and rational exploitation, reconciling sustainability with economy (Biondi et al., 2007).

The Altomontana Forests of Southern Brazil occur at altitudes around $700 \mathrm{~m}$ above sea level and is widely associated with mountains of the Serra do Mar Plateau in Santa Catarina and Paraná States, as well as the Aparados da Serra Geral in Santa Catarina and Rio Grande do Sul States (Falkenberg and Voltolini, 1995). The very steep slopes, cliffs and rocky walls of the Aparados da Serra Geral, volcanic in the highest parts, but with sandstone portions exposed in lower parts, are the eastern edge of the South-Brazilian Plateau in southern Santa Catarina (SC). and northeast of Rio Grande do Sul (RS), where the altitudes fall from 1000-1800 $\mathrm{m}$ at the top of Serra Geral to $100-800 \mathrm{~m}$ at its foot, along a narrow Northeast-Southwest $\left(27^{\circ} 48^{\prime}-29^{\circ} 21^{\prime}\right.$ If $\left.49^{\circ} 15^{\prime}-50^{\circ} 10^{\prime} \mathrm{W}\right)$.

The biodiversity of the fields in Santa Catarina is partially known. Among the flora of altitude fields there are a large number of endemics, and Longhi-Wagner (2003) believes that many new quotes should be made in Santa Catarina. Generating biodiversity information is essential to maintaining the link between scientific knowledge and conservation decision-making (Backes and Irgang, 2004). According to Leite (2002), the Atlantic Forest biome occupies an area of $15 \%$ of the national territory, presenting a series of formations, including the Mixed Ombrophilous Forest and the Campos de Cima da Serra, also called Altitude Fields. Recent studies have counted no less than 1,087 species of flora in the fields of southern Brazil, demonstrating their biological richness (Probio, 2003).

The Serra do Oratório, located in the municipality of Bom Jardim da Serra, Santa Catarina, may be a potential cradle of rare and endemic native species and has been the object of study because it encompasses an area of altitude, mountain slope, wetlands and nebular forests. A few kilometers further north of the Serra do Rio do Rastro is the Oratorio Mountain Range, which was the oldest mountain climb in the region, already used in the 19th century for the movement of freighter troops and cattle descent. For many years, Serraria Gaúcha had a steel cableway installed to beam down lumber for export at the port of Laguna (Reitz, 1965).

According to the Ministry of the Environment (2007), the cloud forests are associated with the high altitudes of the Aparados da Serra, usually above 1,000 to 1,200 meters of altitude, where the humidity is almost permanent. The vegetation, of small size and naturally fragmented distribution, forms "islands" of vegetation, where the levels of endemism are more pronounced. In the swamps of natural fields there are peat bogs, which are specific associations of plants that develop in water bodies, lakes or lagoons, from the colonization by mosses.
The cold and humid climate that prevails in the region makes the formation of this type of vegetation possible, which in the mapping, the peat bogs are included in the category of natural fields (Brasil, 2007). The Brazilian Atlantic Forest Biome, represented by the Dense / Mixed Ombrophilous Forest (Araucaria Forest), together with the Campos de Altitude (Grassy-Wood Steppe) areas, gives this region a remarkable scenic beauty that shelters a great diversity of species. fauna and Flora. This environment is threatened due to disorderly exploitation of land, which leads to soil degradation and compromises water quality (Brasil, 2007).

Due to the diversity of landscapes, the southern region has a great variety of plant species, many with untapped ornamental potential (Coradin et al., 2011). The Serra do Oratório was chosen to be the focus of the present study because it is a site that has difficult access, through streams, peat and rocks, and because species have been found rare and exuberant.

In addition to climatic and environmental characteristics, it is necessary to know the native species as a whole, from their habitat to their pollination, and for this the phenological studies are important. Plant phenology is related to the timing of recurrent events and in particular is poorly understood (Newstrom and Frankie, 1994). In addition to temperature, few studies have evaluated the effect of other environmental factors such as rainfall, photoperiod, soil nutrient availability or physical soil properties and, consequently, evidence its impact on phenology remains scarce (Badeck et al., 2004).

The lack of studies on the flora, use and management of native species of the Southern Highlands of Santa Catarina is a problem that hinders the conservation of local flora and impedes its commercial use, as there is no guidance on possible replacement of exotic plants. by native plants. In addition, different plant and species families require in-depth studies of their phenology and behavior so that they can later be produced on a commercial scale. The aim of the present study is to select five native species with ornamental potential in the Serra do Oratorio in Santa Catarina for phenological studies and to correlate them with climatic factors.

\section{Material and Methods}

\section{Study area}

The work was carried out in the Serra do Oratório countryside formations, located in the state of Santa Catarina, in the municipality of Bom Jardim da Serra. The region is situated on the Santa Catarina Plateau, with altitude around $1,300 \mathrm{~m}, 28^{\circ} 20^{\prime} 25^{\prime \prime} \mathrm{S}-49^{\circ} 37^{\prime} 29^{\prime \prime} \mathrm{W}$. It has a predominant $\mathrm{Cfb}$ climate (rainy and characterized by winters and mild summers) according to the Köppen classification. The area is located in the Pelotas River Basin, with a soft-wavy to wavy topography, and its fields, called "Altitude Fields" are inserted in the Atlantic Forest Biome (IBGE, 2012).

The beautifully scenic Serra do Rio do Rastro is visited by tourists all year round. The average annual temperature 
is $13{ }^{\circ} \mathrm{C}$, being common also to the occurrence of snow in the colder months. The climate is characterized as mild mesothermal, with the coldest month temperature $\geq 10$ and $<11.5^{\circ} \mathrm{C}$. The average normal temperature of the maximum ranges from 19 to $21^{\circ} \mathrm{C}$ and the minimum of 8 to $10^{\circ} \mathrm{C}$ (Ciram, 2020). The relief consists of the Lages Plateau, River Plains and Serra Geral (Embrapa, 1998) units, as a combination of some types of soils: Cambisol (12.8\%), Litolic Neosol (86.1\%) and Nitosol (1.1\%) (Epagri, 2002).

\section{Studied Species}

From a floristic survey conducted on site, five characteristic species of the region were selected: Calibrachoa sellowiana; Tibouchina dubia; Baccharis nummularia; Trichocline catharinensis and Verbena rigida. Such species have ornamental potential, according to Natal et al. (2007). In plants these characteristics can be manipulated through their physical qualities, which are the raw material of aesthetics and beauty. The five species studied were chosen in the study area because they have favorable characteristics for use in landscaping. In addition, because their phenology and characteristics are virtually unknown to the general population, some species may be at risk of extinction.

Collection, herborization and identification of collected material

Field trips were carried out monthly during twelve months (August 2016 to July 2017), following all phenological stages of the studied species, however the collections were intensified in the area especially from December to March, which are the hottest months. of the year and the species were in full bloom, which facilitates the subsequent identification and confirmation of the species in the laboratory. The floristic survey was made through the Walking Method, which consists in drawing parallel imaginary lines along the area to be sampled, in a larger sense and walking slowly through it, collecting fertile individuals of the species found along the way (Filgueiras et al., 1994). In addition, random collections were performed in the surrounding areas.

Samples of fertile plants were collected to make exsiccates and duplicates according to material availability. They were duly selected, included in newspaper, interspersed with cardboard, and on wooden presses of internationally standardized size, according to the commonly known procedure and used in vascular plant herborization (Mori et al., 1989). The samples were placed in an electric oven at approximately $60{ }^{\circ} \mathrm{C}$ for about five days for drying and storage. The data for each plant, duly recorded in a field book, were later entered, standardized according to the LUSC Herbarium form of the State University of Santa Catarina (UDESC). After the assembly of the exsiccates and identification, the plants were duly registered and incorporated into the collection of the LUSC Herbarium.

Species were identified using a stereomicroscope and taxonomic keys from regional floras such as Santa Catarina Illustrated Flora and neighboring regions floras, as well as revision studies of the Asteraceae, Verbenaceae, Solanaceae and Melastomataceae families.

\section{Phenology of Species}

Five individuals of each species were marked for phenological observations at monthly intervals. Subjects were marked with 1-5 metal cuttings and platelets. Observations were conducted monthly in five individuals of each species from August 2016 to July 2017. During this period, the following phases were recorded: dormancy, vegetation, flower buds or visible inflorescences, full bloom, fruiting and fruit ripening.

To verify if the phenological events are correlated with climatic factors, Spearman correlation analysis (rs) was used. Plant phenophases were correlated with meteorological data obtained from the National Institute of Meteorology (INMET). The meteorological data correlated with the phenophases were maximum and minimum temperature $\left({ }^{\circ} \mathrm{C}\right)$ and precipitation $(\mathrm{mm})$ and insolation (h). In addition, data on plant habit, ecology (sun, shade, half shade) and type of substrate the plants were on (rocky, wet, peaty, sandy, clayey) were also collected. All species studied were planted and identified in the LUSC Herbarium. For the conference of the spelling of scientific names and the authorship of specific epithets, the Missouri Botanical Garden's electronic database (Trópicos, 2006) was consulted.

\section{Aesthetic analysis of the studied species}

For the present study we used the methodology of Biondi (1990), where the plants are analyzed aesthetically according to specific characteristics, as follows:

a) Line and shape - in plants what determines the line are the trunk and branches; and the shape, volume mass of the canopy or foliage. The plants that are most contoured in shape, that is, geometrically defined shape, are trees and shrubs. The others have no definite shapes and can be modeled more easily, assuming different shapes.

b) Color - colors are expressed through flowers, fruits, twigs, buds, trunk and foliage. Many of these elements, however, are not seen permanently because they are seasonal.

c) Size - Size reflects the harmonious relationship between height, canopy or foliage diameter and trunk or branch diameter.

d) Texture - In landscaping, texture is not judged by tactical experience, but by the visual qualities that plants offer. The limiting factor for assessing a texture is the distance from the observer. When the distance is close, the texture is a result of the size, shape, surface quality and space of the leaves, the stiffness of the petioles and branches. And when the distance is long, the individual details are diluted, and the texture is the result of the light and shade that the plant provides to the site.

e) Structure - is the end product of the different effects from the component parts of the plant, such as: canopy or foliage, trunk or branch. The structure of the plant can be classified as: light (combination between not very dense canopy with fine textured leaves, flexible branches, thin 
and apparently smooth stem) or heavy (combination between dense canopy with thick textured leaves, woody branches and thick stem) woody).

f) Symmetry - In plants symmetry depends on the type of branch forming the crown or foliage and the direction of its growth. When the branch forming the canopy or foliage is part of a major (racemose) axis and the growth of that axis is continuous and the branching is limited (monopodial growth), the plant is likely to be symmetrical. And when the canopy or foliage branch part of a short main axis with successive branches (cimosa) and the growth of that axis is limited and the branch growth is unlimited (sympodial growth), the plant will have an asymmetrical tendency.

\section{Soil analysis}

Soil classification was performed through visual and tactile analysis of the surface layer along with the physicochemical analysis of collected soil, obtaining samples from different points (Chamas and Matthes, 2000). The samples were analyzed at the UDESC Soil Analysis Laboratory. The areas around the plants selected for phenology were demarcated in $1 \mathrm{~m}^{2}$ plots from which 1 soil sample was randomly collected per individual. The collection was performed using a straight shovel and auger, and each sample taken at a depth of $0-30 \mathrm{~cm}$ was well mixed with samples from individuals of the same species, thus obtaining a composite sample with approximately 300 grams of soil. Each sample was placed in a clean plastic bag, along with the identification label. In the area under native vegetation, before the samples were collected, the pasture present on the soil surface was removed. The following elements were quantified: M.O (organic matter, $\mathrm{pH}$ in water, calcium, magnesium, aluminum, sodium, potassium, hydrogen + aluminum and the effective cation exchange capacity).

\section{Results and Discussion}

Of the five species studied, Calibrachoa sellowiana, Trichocline catharinensis e Verbena rigida have herbaceous bearing; Baccharis nummularia and Tibouchina dubia bushy bearing (Table 1).

Table 1. Species studied and their physical characteristics for ornamentation.

\begin{tabular}{|c|c|c|c|c|c|c|c|c|c|}
\hline Species & Bearing & Ecology & Substrate & $\begin{array}{l}\text { Leaf } \\
\text { Color }\end{array}$ & $\begin{array}{l}\text { Flower } \\
\text { Color }\end{array}$ & Texture & Line & Structure & Symmetry \\
\hline Baccharis nummularia & A & S & $\mathrm{T}$ & VM & $\mathrm{BR}$ & G & $\mathrm{V}$ & $\mathrm{P}$ & S \\
\hline $\begin{array}{c}\text { Calibrachoa } \\
\text { sellowiana }\end{array}$ & $\mathrm{H}$ & $\mathrm{S}$ & $\mathrm{R}$ & $\mathrm{VC}$ & ROS & $\mathrm{F}$ & $\mathrm{C}$ & $\mathrm{L}$ & A \\
\hline Tibouchina dubia & A & S & $\mathrm{T}$ & VM & ROX & $\mathrm{F}$ & V & $\mathrm{L}$ & S \\
\hline $\begin{array}{c}\text { Trichocline } \\
\text { catharinensis }\end{array}$ & $\mathrm{H}$ & S & $\mathrm{T}$ & VE & $\mathrm{AM}$ & $\mathrm{F}$ & $\mathrm{C}$ & $\mathrm{L}$ & S \\
\hline Verbena rigida & $\mathrm{H}$ & S & $\mathrm{R}$ & $\mathrm{VC}$ & LIL & $\mathrm{F}$ & $\mathrm{C}$ & $\mathrm{L}$ & A \\
\hline
\end{tabular}

BEARING $=$ herbaceous $(\mathrm{H})$, shrub (A), sub-shrub (S.A)

ECOLOGY $=$ sun $(\mathrm{S})$, shadow $(\mathrm{SO})$, half shadow $(\mathrm{MS})$

SUBSTRATE $=$ rocky $(R)$, plated $(B)$, peaty $(T)$, sandy $(A)$, clayey $(A R)$

LEAF COLOR = color of leaves: V.C. = light green; V.M. = medium green; E. = dark green

FLOWER COLOR = color of flowers: Am. = Yellow; Be. = beige; Br. = White; Rox. = purple; Viol. = violet;

Lil = lilac; Az. = Blue; Verm. = red; Ros. $=$ pink; Home. $=$ orange;

TEXTURE: $\mathrm{F}=$ thin; $\mathrm{G}=$ coarse;

LINE: $\mathrm{V}=$ vertical; $\mathrm{C}=$ curve;

STRUCTURE: L = light; P. = heavy;

SYMMETRY: S. = symmetrical; As. = Asymmetric.

Source: author (2017). Table based on methodology of Biondi (1990). 
The size of the plants is of paramount importance in the design of a landscape project, which influences in order to become decisive in choosing a species to compose a garden bed or part of a garden. The visual effects that ornamental plants can produce are associated with the groups or types they belong to (trees, shrubs, vines, herbs, etc.) and the particular attributes of each plant, such as the effect of flowers or showy foliage (Lorenzi and Souza, 2001), therefore, it can be inferred that the plants studied present options to landscape designers for the elaboration of landscape projects. All species evaluated in this work occur in full sun ecology (Table 1), this characterizes them as heliophytic plants. The high number of plants in fields living in full sun can be confirmed by Biondi et al. (2007), when they followed phenological events of 12 native species of fields, where all the studied species were also in full sun.

Among the evaluated species, Calibrachoa sellowiana and Verbena rigida are conditioned on rocky substrate, while Baccharis nummularia, Tibouchina dubia and Trichocline catharinensis are found on peat substrate. Two species (Baccharis nummularia and Tibouchina dubia) have medium green leaves, two other species (Calibrachoa sellowiana and Verbena rigida) have light green leaves and Trichocline catharinensis have dark green leaves (Table 1).

The color of the petals was varied among species, being white (Baccharis nummularia), roses (Calibrachoa sellowiana), purple (Tibouchina dubia), yellow (Trichocline catharinensis) and lilacs (Verbena rigida) (Table 1). Landscaping, in addition to conferring beauty in its shapes and colors, contributes in various ways in the lives of those who make use of plants for contemplation or even therapeutic purposes, promoting health and well-being (Van den Berg, 2017). Baccharis nummularia presented coarse texture and heavy structure, distinguishing it from the other species that presented fine texture and light structure. Ornamental plants offer a variety of textures that, if well designed, will provide great visual effects. Fine textures, for example, have the property of giving the impression of rest by the visual relaxation they provide (Lira Filho et al., 2002) as opposed to the thick textures of plants that impact.

Baccharis nummularia and Tibouchina dubia presented vertical lines, in contrast the other species were classified as having horizontal lines (Table 1), with creeping aspect. The line is the simplest and most primitive element in the process of visual communication, being present in almost all landscape components (Lira Filho et al., 2002) and can be used in landscape projects conferring different sensations to observers.

For each species, different behaviors regarding the time of occurrence and the intensity of the phenophases were observed, as well as the relationship between these characteristics and the annual variation of the climatic indices found in the Oratorio Mountains.

\section{Baccharis nummularia (broom)}

From December to August the Baccharis nummularia species was in vegetative stage, without the presence of any reproductive structures (Table 2 ).

Table 2. Phenology of native species with ornamental potential in the Serra do Oratório - Santa Catarina, in the 2016/2017 cycle.

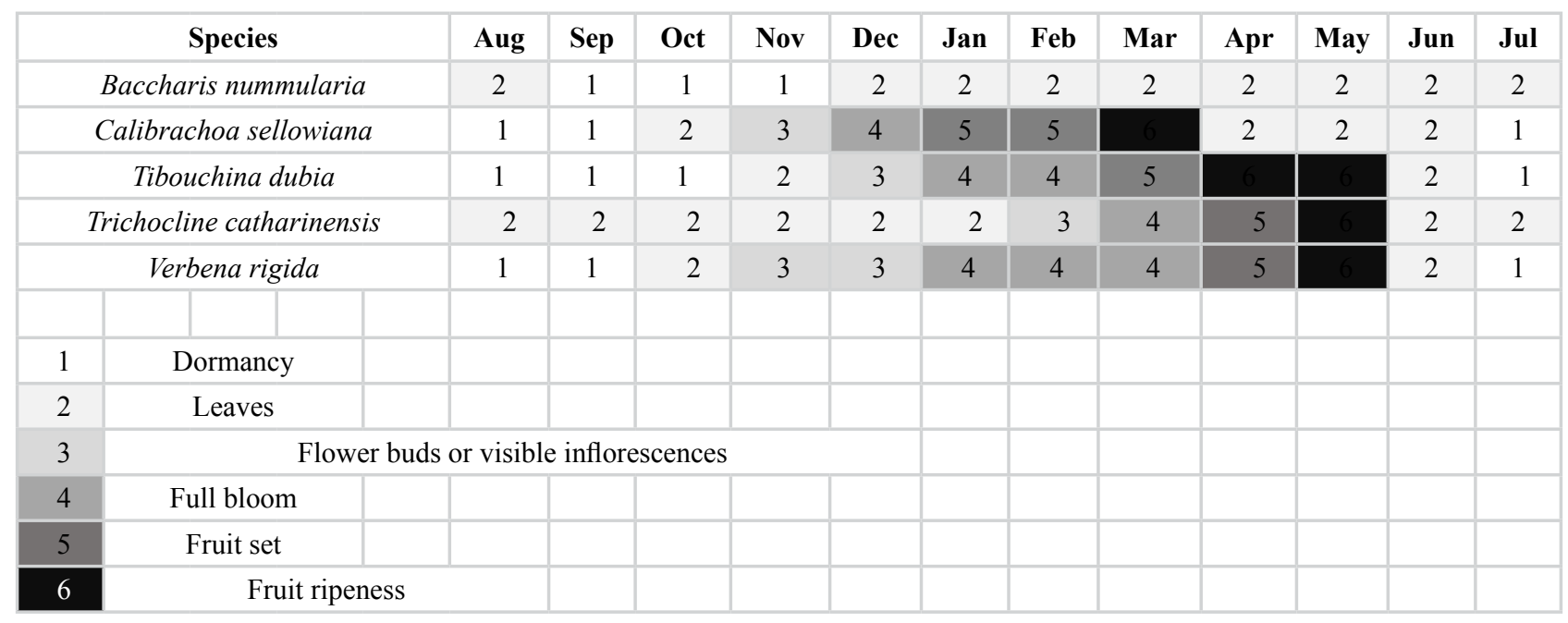

Source: author (2017)

The events observed in the present study are in agreement with the results found by Barroso and Bueno (2002), where the authors state that the Baccharis nummularia species preferentially blooms from October to February. From September to November, probably due to the low rainfall, the plants of this species dried up and had their vegetative part compromised, leaving only the stem of the plants. Although the study site has native plants, it is a private plot, with some grazing areas for cattle, and as usual in the region of the Santa Catarina Plateau, between June and August, was burned in some parts of the ground. Most of the inhabitants consider the "broom" as 
an invasive species of pastures, and for this reason, they also make use of fire in these species. Possibly due to the use of fire in the pasture of the site, the species Baccharis nummularia was not successful in completing its cycle during the study period. During the twelve-month period of field evaluation, the flowering was not observed, probably due to meteorological and anthropic events during the 2016/2017 cycle.
At the beginning of the evaluations the Baccharis nummularia species presented vegetative activity in August 2016, but during the months of September and October, a dormancy period was observed (Figure 1).

The occurrence of numbness decreased in November, with the increase of the minimum temperature, presenting a negative correlation (Table 3 ).
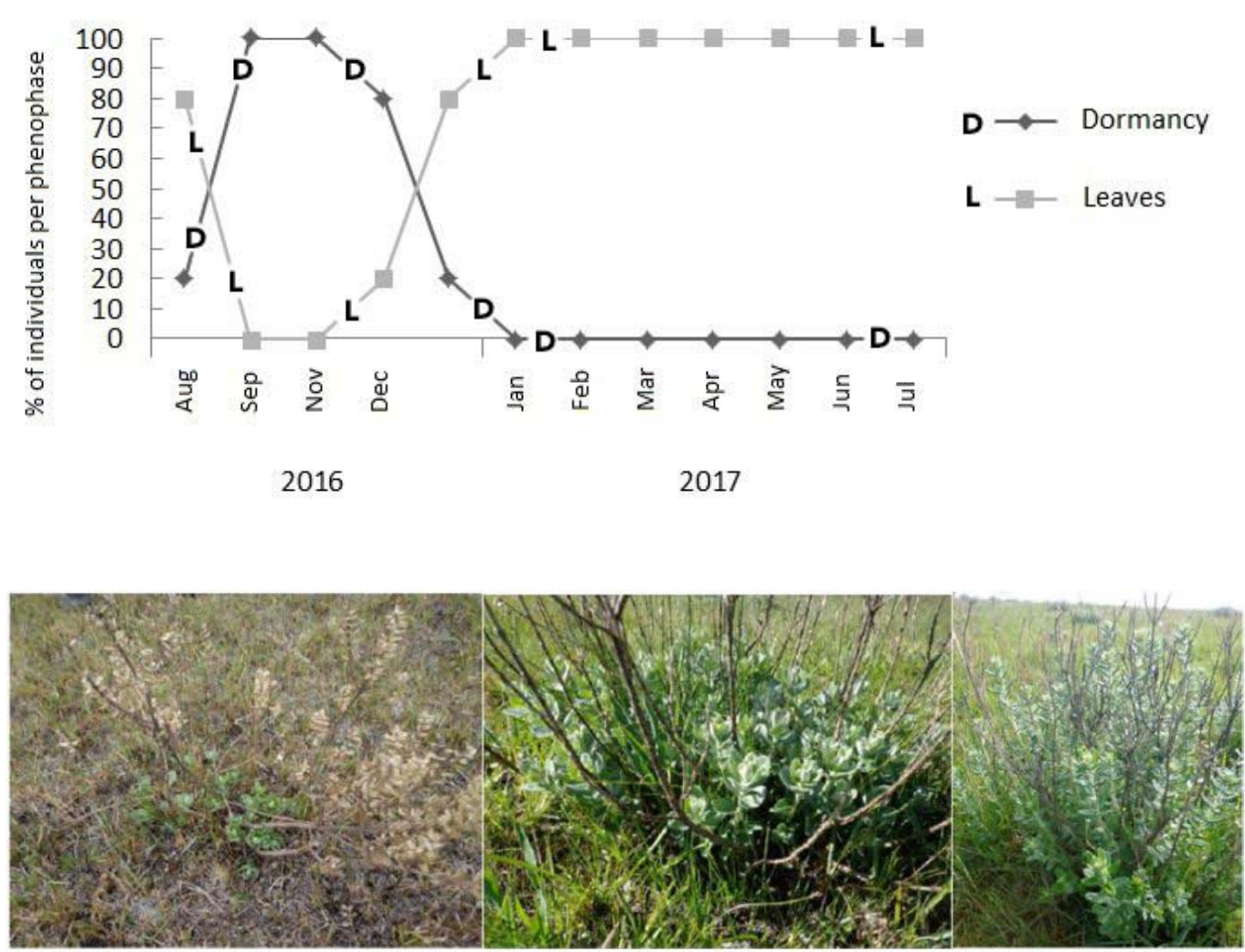

Figure 1. Percentage (\%) of individuals in Baccharis nummularia vegetative and reproductive phenophases in Serra do Oratório, from August 2016 to July 2017.

Source: author (2017).

Table 3. Spearman correlations (rs) between Baccharis nummularia phenophases and environmental variables in Serra do Oratório, from August 2016 to July 2017. Correlation coefficients in bold are significant $(p \leq 0.05)$.

\begin{tabular}{|c|c|c|c|c|c|}
\hline \multirow{2}{*}{ Phenophase } & $\begin{array}{c}\text { Average } \\
\text { temperature }\end{array}$ & Max temperature & Min temperature & Precipitation & Insolation \\
\hline & $\left({ }^{\circ} \mathrm{C}\right)$ & $\left({ }^{\circ} \mathrm{C}\right)$ & $\left({ }^{\circ} \mathrm{C}\right)$ & $(\mathbf{m m})$ & (h) \\
\hline \multirow{2}{*}{ Dormancy } & $-0.109 *$ & 0 & -0.36 & -0.0218 & 0 \\
\hline & $\mathrm{ns}^{* *}$ & ns & 0.0049 & ns & ns \\
\hline \multirow{2}{*}{ Leaves } & -0.109 & 0 & 0.36 & 0.338 & -0 \\
\hline & Ns & ns & 0.0049 & 0.0084 & $\mathrm{~ns}$ \\
\hline
\end{tabular}

Source: author (2017)

*correlation coefficient; **significance level (p value); ns = non-significant. 
From November the plants started the sprouting that extended throughout the evaluation period until July 2017. The vegetative growth behavior was positively related to the increase of the minimum temperature and water availability, represented by rainfall. Throughout the evaluated cycle, no plants with reproductive structure development were observed.

Although Baccharis nummularia is a well-known species and easily propagated in the native field, atypical events should not be considered to justify their phenophases. Collections made over a year often do not represent the ornamental flora of the area, because many species may not be manifested by climatic factors or even biological rhythms (Chamas and Matthes, 2000). Still, some species of the genus Baccharis have the visual aspects required by consumers, they are frequent plants in the local landscape and are adapted to the climatic conditions of the region, besides showing a rustic aspect, which can be an advantage for their cultivation, without that there is a need for protected cultivation or high technology for production, making it an alternative for the floricultural segment without infrastructure (Tognon and Cuquel, 2016).

This species has geographic distribution in the southern states of Brazil: Paraná, Rio Grande do Sul and Santa Catarina. In these states, in the municipalities of Bom Jardim da Serra, Campo Alegre, Garuva, and Urubici. as a potential use in landscaping the species can be used in the formation of hedges, paths, and extensive gardens with topiary. Although considered an invasive species, there was a strong potential for the use of Baccharis nummularia for landscaping, even though it is a native and endemic species from Brazil, which shows that the population does not accept or consider the species. as potential for ornamental use in landscaping.

Examined material: BRASIL. SANTA CATARINA: Bom Jardim da Serra, April $28^{\text {th }}$ 2017, F.E.A.Bastos 9021 (LUSC).

\section{Calibrachoa sellowiana (petunia)}

During the months of July and September the species was dormant and leafless in the shoots, but the rhizomes were present in rocky substrate. In October the species began to have new leaf shoots and, therefore, entered a vegetative state. In November, flower bud formation began and in December the evaluated plants began to bloom. In January and February Calibrachoa sellowiana presented fruiting and the following month the fruits were ripe. From April to June, after fruiting, only the vegetative part was visible (Table 2).

The vegetative cycle of Calibrachoa sellowiana species begins in September, when about $20 \%$ of individuals were emerging from dormancy and sprouting, reaching $100 \%$ of vegetative activity in October (Figure 2). Flower buds were present in $100 \%$ of the plants evaluated in November. Fruit ripening occurred in all plants evaluated in March 2017.

The Calibrachoa sellowiana phenological cycle, especially the vegetative period and the flowering, fruiting and fruit ripening phenophases were highly influenced by the fluctuation of average, maximum and minimum temperatures, as well as rainfall (Table 4). 


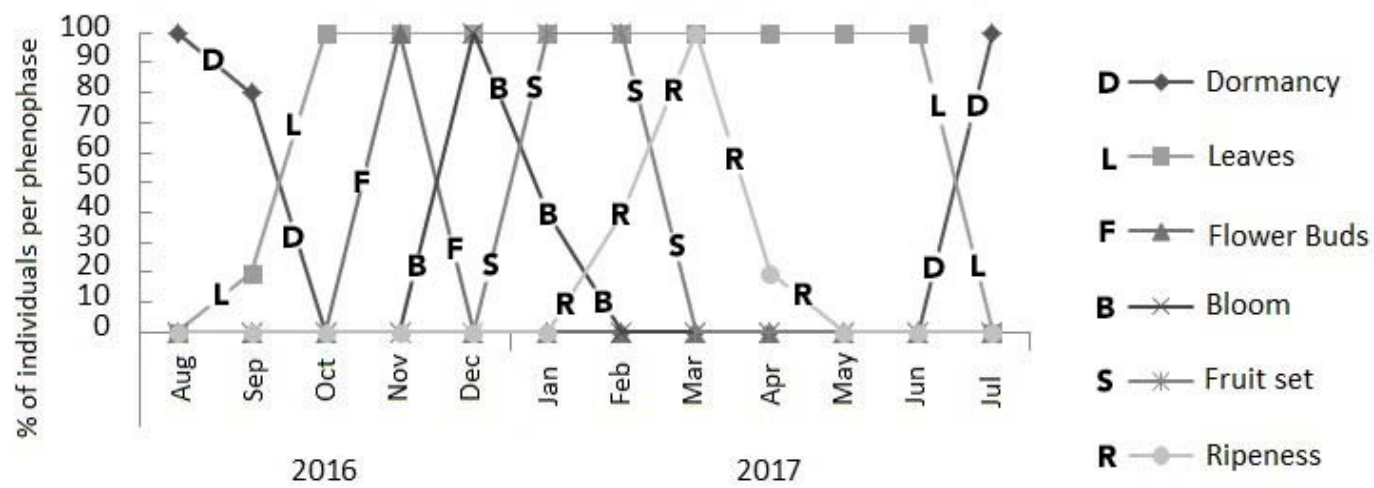

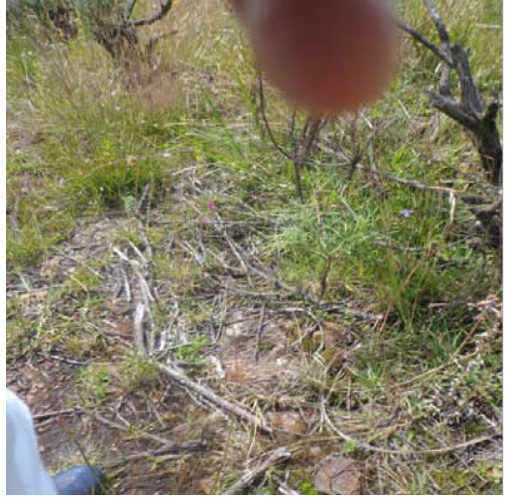

FOLIAGE

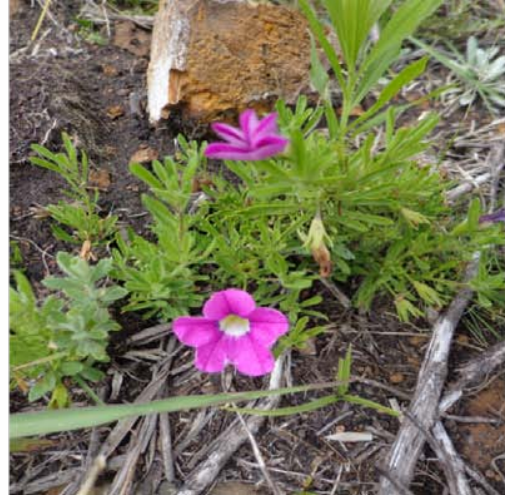

FLOWERING

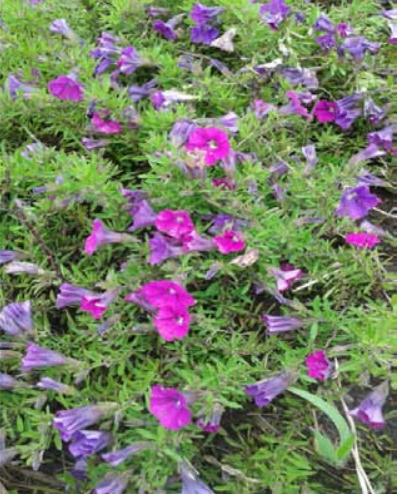

FULL BLOOM

Figure 2. Percentage (\%) of individuals in the vegetative and reproductive phenophases of Calibrachoa sellowiana in Serra do Oratório, from August 2016 to July 2017. Source: author (2017).

Table 4. Spearman correlations (rs) between Calibrachoa sellowiana phenophases and environmental variables in Serra do Oratório, from August 2016 to July 2017. Correlation coefficients in bold are significant $(p \leq 0.05)$.

\begin{tabular}{|c|c|c|c|c|c|}
\hline \multirow{2}{*}{ Phenophase } & Average temperature & Max temperature & Min temperature & Precipitation & Insolation \\
\hline & $\left({ }^{\circ} \mathrm{C}\right)$ & $\left({ }^{\circ} \mathrm{C}\right)$ & $\left({ }^{\circ} \mathrm{C}\right)$ & $(\mathbf{m m})$ & (h) \\
\hline \multirow{2}{*}{ Dormancy } & $-0.571^{*}$ & -0.525 & -0.708 & -0.514 & -0.0799 \\
\hline & $<.0001 * *$ & $<.0001$ & $<.0001$ & $<.0001$ & ns \\
\hline \multirow{2}{*}{ Leaves } & 0.571 & 0.525 & 0.708 & 0.514 & 0.0799 \\
\hline & $<.0001$ & $<.0001$ & $<.0001$ & $<.0001$ & ns \\
\hline \multirow{2}{*}{ Flower bud } & 0.131 & 0.131 & 0.0437 & -0.306 & 0.48 \\
\hline & ns & Ns & Ns & 0.0178 & $<.0001$ \\
\hline \multirow{2}{*}{ Bloom } & 0.399 & 0.399 & 0.399 & 0.308 & 0.218 \\
\hline & 0.0017 & 0.0017 & 0.0017 & 0.0168 & ns \\
\hline \multirow{2}{*}{ Fruit set } & 0.648 & 0.648 & 0.648 & 0.0648 & 0.259 \\
\hline & $<.0001$ & $<.0001$ & $<.0001$ & ns & 0.0457 \\
\hline \multirow{2}{*}{ Ripeness } & 0.353 & 0.353 & 0.353 & 0.353 & 0.203 \\
\hline & 0.0058 & 0.0058 & 0.0058 & 0.0058 & ns \\
\hline
\end{tabular}

Source: author (2017)

*correlation coefficient; $* *$ significance level ( $\mathrm{p}$ value); $\mathrm{ns}=$ non-significant. 
Such phenophases were positively correlated with increasing temperature and water availability. Dormancy was inversely correlated with temperatures (average, maximum and minimum) and precipitation, and the appearance of flower buds seems to be a response to increased insolation. In a study by Kanaya et al. (2010), when studying the morphological diversity of the popular Calibrachoa ornamental culture, commercialized since the 1990s, compared floral and vegetative characters of 91 commercial cultivars with those of native species. Similar results were found to those of the present study. The authors state that most natural species and cultivars (including Calibrachoa sellowiana) bloomed from late spring to early summer, and after that time flowering declined. Still according to the same authors, Calibrachoa is one of the most important creeping ornamental plants, especially in temperate climates.

This plant can be used to line beds, along with tree species to compose paths and long beds, forming massifs. The species can replace exotic petunias. Calibrachoa sellowiana forms sparse populations in the Oratory mountain range, by roadside, hill slopes, in rocky places. It is easily found when in full bloom due to the vibrant color of its corolla.

Examined material: BRASIL. SANTA CATARINA: Bom Jardim da Serra, November $16^{\text {th }}$ 2013, N.S. Aguiar and M.J. Antoniutti 8081 (LUSC).

\section{Tibouchina dubia (manacá-serrano)}

From July to October, the species was dry with no leaves or any reproductive structure. From November, the plants selected for the study began to sprout in the basal branches of the plant, beginning its vegetative period. In December the plant was lush with shoots and flower buds. Between January and February, there was a full flowering of plants that in March culminated with fruiting. Between April and May, the fruits were ripe and with seeds dispersing. In June, with winter, the plant went dormant and only its vegetative part became visible (Table 2).

For the Tibouchina dubia species, with the exception of dormancy, for all phenophases, positive responses to the increase in average, maximum and minimum temperatures were observed (Table 5).

Table 5. Spearman correlations (rs) between Tibouchina dubia phenophases and environmental variables in Serra do Oratório, from August 2016 to July 2017. Correlation coefficients in bold are significant $(p \leq 0.05)$.

\begin{tabular}{|c|c|c|c|c|c|}
\hline \multirow[t]{2}{*}{ Phenophase } & $\begin{array}{c}\text { Average } \\
\text { temperature }\end{array}$ & Max temperature & Min temperature & Precipitation & Insolation \\
\hline & $\left({ }^{\circ} \mathrm{C}\right)$ & $\left({ }^{\circ} \mathrm{C}\right)$ & $\left({ }^{\circ} \mathrm{C}\right)$ & $(\mathbf{m m})$ & (h) \\
\hline \multirow{2}{*}{ Dormancy } & $-0.543 *$ & -0.451 & -0.748 & -0.338 & 0.0102 \\
\hline & $<.0001 * *$ & 0.0003 & $<.0001$ & 0.0084 & ns \\
\hline \multirow{2}{*}{ Leaves } & 0.543 & 0.451 & 0.748 & 0.338 & -0.0102 \\
\hline & $<.0001$ & 0.0003 & $<.0001$ & 0.0084 & ns \\
\hline \multirow{2}{*}{ Flower bud } & 0.353 & 0.353 & 0.338 & 0.233 & 0.248 \\
\hline & 0.0057 & 0.0057 & 0.0083 & ns & ns \\
\hline \multirow{2}{*}{ Bloom } & 0.668 & 0.668 & 0.668 & 0.106 & 0.268 \\
\hline & $<.0001$ & $<.0001$ & $<.0001$ & ns & 0.0384 \\
\hline \multirow{2}{*}{ Fruit set } & 0.353 & 0.353 & 0.353 & -0.353 & 0.203 \\
\hline & 0.0057 & 0.0057 & 0.0057 & 0.0057 & ns \\
\hline \multirow{2}{*}{ Ripeness } & -0.0648 & -0.194 & 0.0648 & 0.389 & -0.518 \\
\hline & ns & ns & ns & 0.0022 & $<.0001$ \\
\hline
\end{tabular}

Source: author (2017)

*correlation coefficient; **significance level (p value); ns = non-significant.

The Tibouchina dubia phenological cycle was correlated with average, maximum and minimum temperatures during dormancy, the vegetative period, the presence of flower buds, full flowering and fruiting (Table 5). Vegetative stage and fruit maturation were positively correlated with rainfall. Dormancy was inversely correlated with temperatures (average, maximum and minimum) and precipitation. All individuals showed foliage from November to June, when the plants had their leaves dried and / or senescent (Figure 3). 


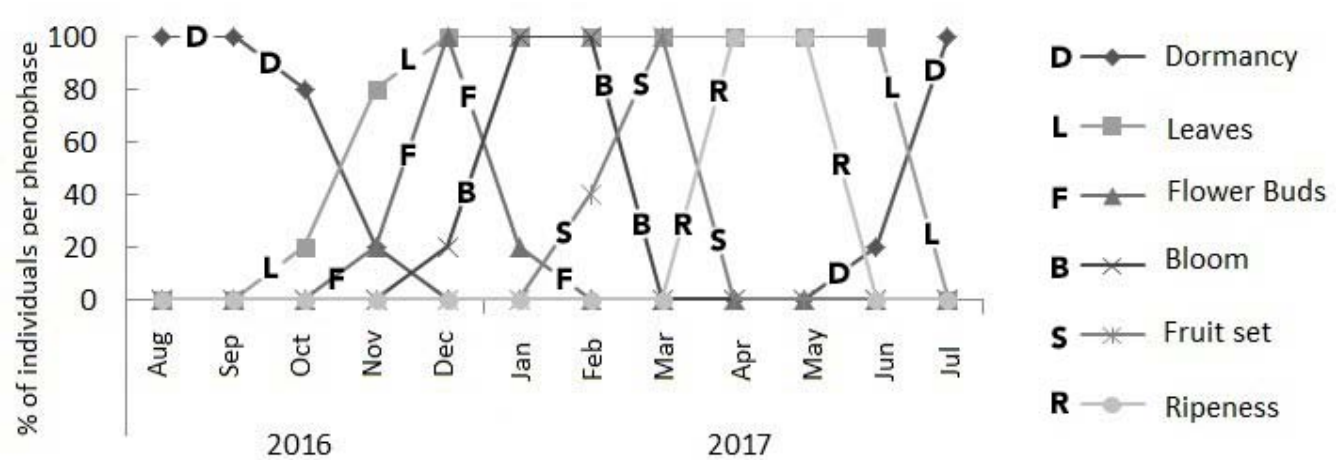

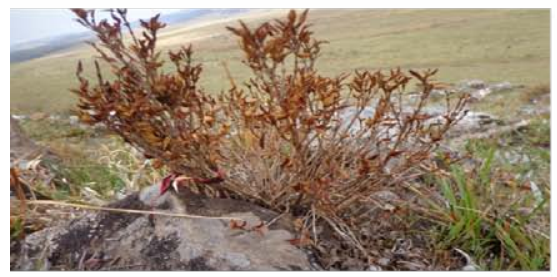

FLOWERING

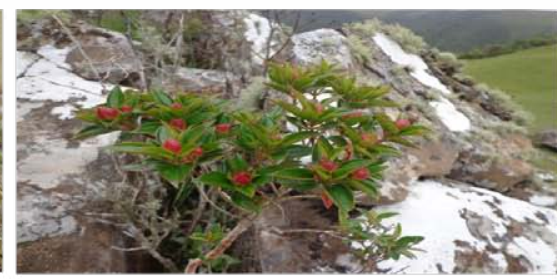

FULL BLOOM

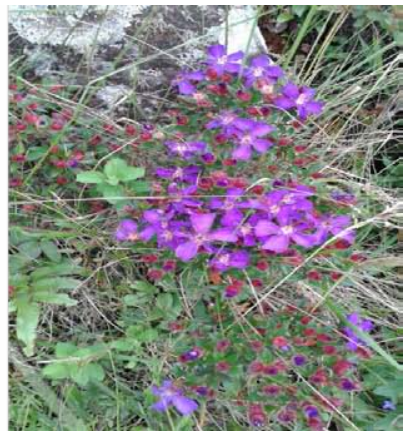

FULL BLOOM

Figure 3. Percentage (\%) of individuals in the vegetative and reproductive phenophases of Tibouchina dubia in Serra do Oratório, from August 2016 to July 2017.

Source: author (2017).

In phenological studies in Campo areas in Paraná, conducted by Martini et al. (2010), similar results were found with the species Tibouchina gracilis, where short flowering periods and long periods of leaf production stagnation were presented, less relevant characteristics. Tibouchina gracilis remains for four months in the flowering phase, seven months in the flowering phase stagnation of leaf production and even a long period of desiccation. Possibly some species of the genus Tibouchina exhibit similar behavior in Campos environments, which according to Roderjan et al. (2002), consists essentially of grasses occurring on soft-undulating terrain, and composes a characteristic element of the landscape of the highlands of southern Brazil, which is the case of the states of Santa Catarina and Paraná.

In Brazil its distribution occurs in São Paulo, Paraná, Santa Catarina and Rio Grande do Sul (Guimarães, 2016). Tibouchina dubia is found in the Serra do Oratório in a high place, under half shadow, forming a small community. It has dense and deep roots that are under stones. Its flowering is very showy and flashy, but of short duration. The species has the potential to be used as a shrub and hedge.

Examined material: BRASIL. SANTA CATARINA: Bom Jardim da Serra, November $16^{\text {th }} 2013$, N.S Aguiar and M.J. Antoniutti 8081 (LUSC).

\section{Trichocline catharinensis (regular carnation)}

From June to January, the species presented turgid and leafy shoots, that is, without signs of numbness. From February the formation of flower buds was verified and in March occurred the full flowering of the evaluated species. From April fruiting began with the fruits being ripe and seeds dispersing in May (Table 2). It was observed that $100 \%$ of the evaluated individuals remained with their foliage throughout the study period (Figure 4). All individuals presented flower buds, full flowering, fruiting and fruit ripening in February, March, April and May, respectively (Figure 4 ).

There was a positive correlation between the temperatures (minimum, maximum and average) for flower bud appearance (Table 6). 


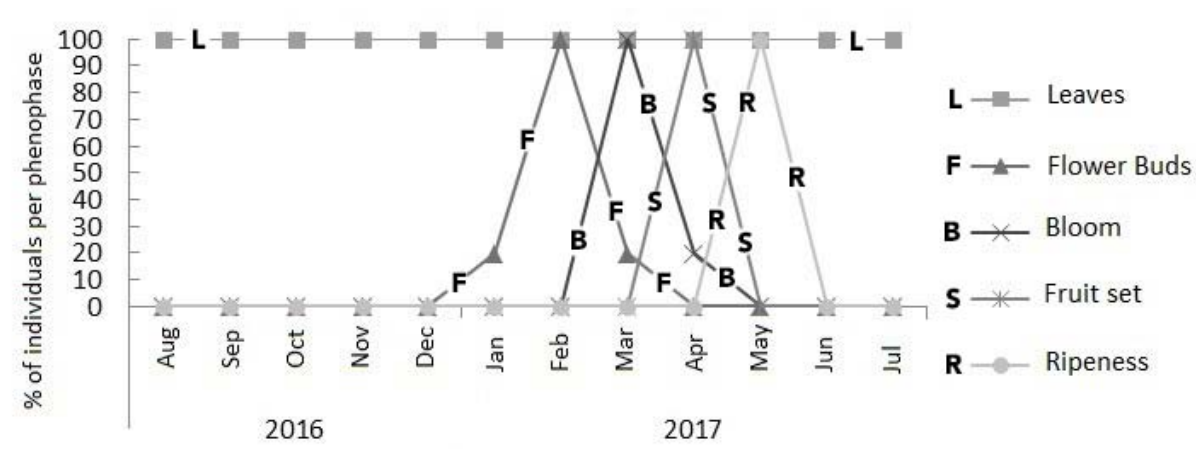

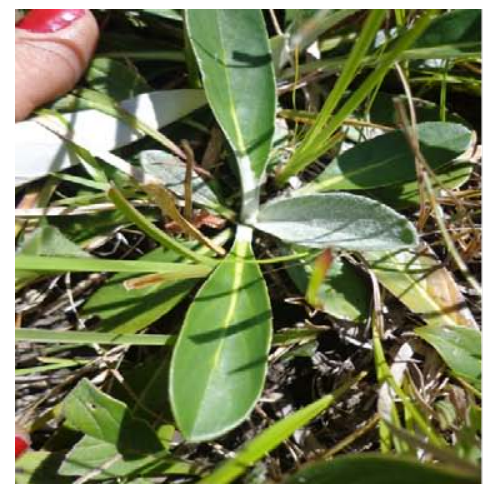

FOLIAGE

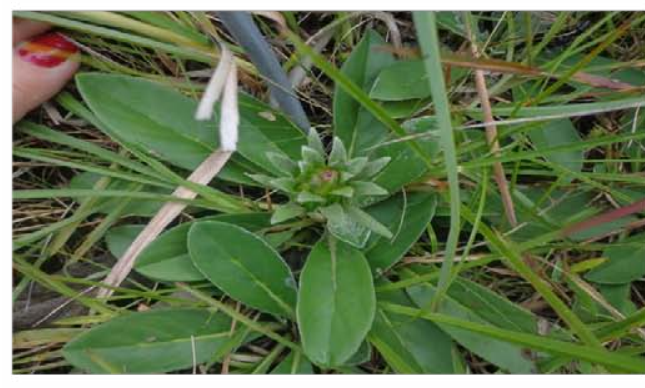

FLOWERING

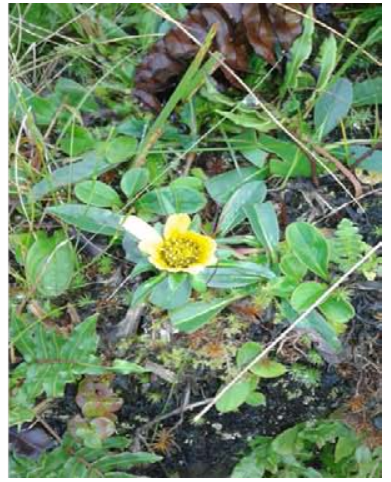

FLOWERING

Figure 4. Percentage (\%) of individuals in the vegetative and reproductive phenophases of Trichocline catharinensis in Serra do Oratório, from August 2016 to July 2017.

Source: author (2017).

Table 6. Spearman correlations (rs) between Trichocline catharinensis phenophases and environmental variables in Serra do Oratório, from August 2016 to July 2017. Correlation coefficients in bold are significant $(p \leq 0.05)$.

\begin{tabular}{|c|c|c|c|c|c|}
\hline \multirow{2}{*}{ Phenophase } & Average temperature & $\begin{array}{c}\text { Max } \\
\text { temperature }\end{array}$ & Min temperature & Precipitation & Insolation \\
\hline & $\left({ }^{\circ} \mathrm{C}\right)$ & $\left({ }^{\circ} \mathrm{C}\right)$ & $\left({ }^{\circ} \mathrm{C}\right)$ & $(\mathrm{mm})$ & (h) \\
\hline \multirow{2}{*}{ Dormancy } & $0^{*}$ & 0 & 0 & 0 & 0 \\
\hline & $\mathrm{ns} * *$ & Ns & ns & Ns & ns \\
\hline \multirow{2}{*}{ Leaves } & 0 & 0 & 0 & 0 & 0 \\
\hline & ns & Ns & ns & Ns & ns \\
\hline \multirow{2}{*}{ Flower bud } & 0.519 & 0.519 & 0.519 & -0.0827 & 0.128 \\
\hline & $<.0001$ & $<.0001$ & $<.0001$ & Ns & ns \\
\hline \multirow{2}{*}{ Bloom } & 0.209 & 0.193 & 0.225 & -0.354 & 0.161 \\
\hline & ns & Ns & ns & 0.0057 & ns \\
\hline \multirow{2}{*}{ Fruit set } & 0.0437 & -0.0437 & 0.131 & 0.0437 & -0.218 \\
\hline & ns & $\mathrm{Ns}$ & ns & Ns & ns \\
\hline \multirow{2}{*}{ Ripeness } & -0.131 & -0.218 & -0.0437 & 0.48 & -0.48 \\
\hline & ns & Ns & ns & $<.0001$ & $<.0001$ \\
\hline
\end{tabular}

Source: author (2017)

* correlation coefficient; **significance level ( $\mathrm{p}$ value); $\mathrm{ns}=$ non-significant. 
Asteraceae has several native genera of great ornamental potential, especially the genus Trichocline sp., whose species closely resemble commercially cultivated gerberas (Livramento, 2011). The species is not yet used by the local population, not even to ornament the surroundings of houses or farmhouses, being considered by many an invasive plant. In evaluations performed by Livramento (2011) in a greenhouse, the predominant flowering begins in late November, extending until March or April. Although these results differed from the present study, it can be stated that the climatic conditions in Serra do Oratório are quite adverse, possibly causing Trichocline catharinensis to bloom for a longer period in a greenhouse, with temperature, humidity. and ideal substrates. In Brazil the species is found in the states of Rio Grande do Sul and Santa Catarina, in the cities of Bom Jardim da Serra, Cacador, Campos Novos, Curitibanos, Lages, Lebon Régis, Sao Jose do Cerrito and Sao Joaquim (Cabrera and Klein, 1973). It can be used in composition of flowerbeds and fills or as a possible vase flower. Trichocline catharinensis has great resistance to frost and adverse weather, which is endowed with regular fogs, high winds and low temperatures, especially in winter.
Examined material: BRASIL. SANTA CATARINA: Bom Jardim da Serra, September $28^{\text {th }}$ 2017, F.E.A.Bastos 9019 (LUSC).

\section{Verbena rigida (regular verbena)}

From July to September, the species did not present reproductive structures, and most individuals presented dry or leafless shoots, only with the presence of their rhizomes (Table 2). According Livramento and Zoldan (2011), Verbena rigida resists frost, remaining dormant under pastures or even vegetating, at which time its leaves acquire a dry and stained aspect, brittle to the touch. Identical characteristics were detected in the present work. From October the species presented its vegetative part. In November and December began the appearance of flower buds. Between January and March, the species was found in full bloom, bearing fruit in April. In May, at the end of the cycle, the plant had its ripe fruits (Table 2). In natural conditions, it reappears in the landscape at the end of winter, sprouting vigorously from rhizomes and stolons, where $100 \%$ of its individuals were in the vegetative stage (Figure 5).

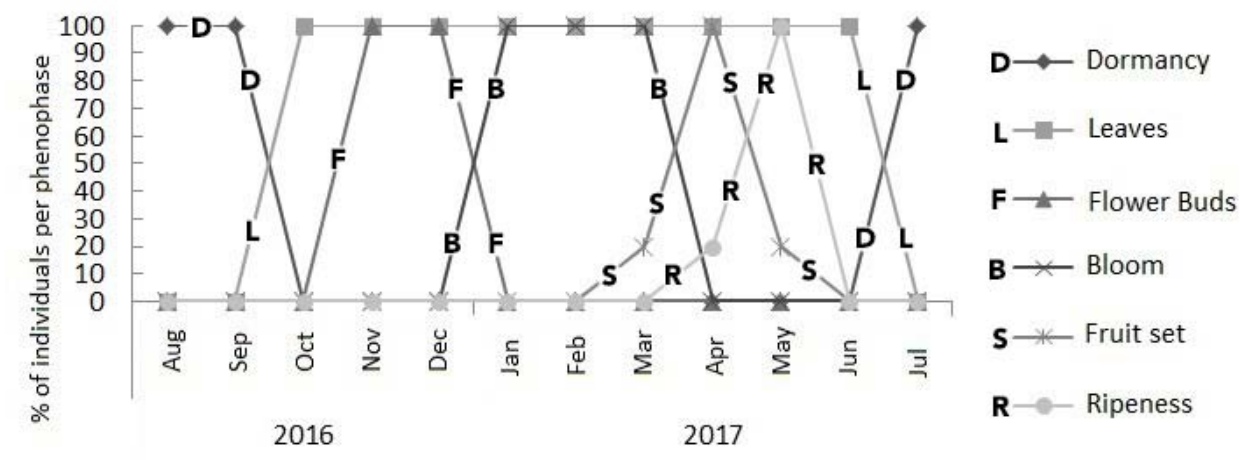

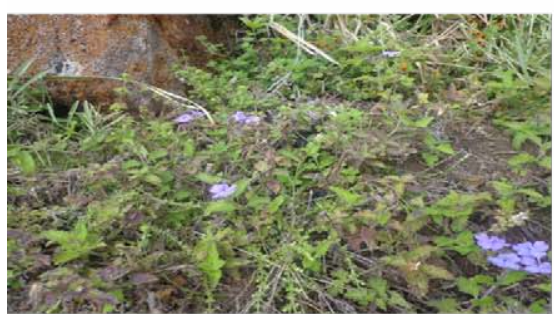

FOLIAGE

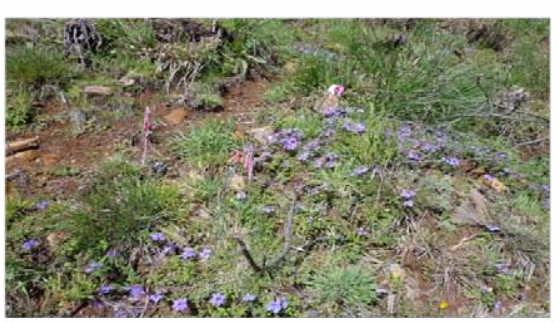

A

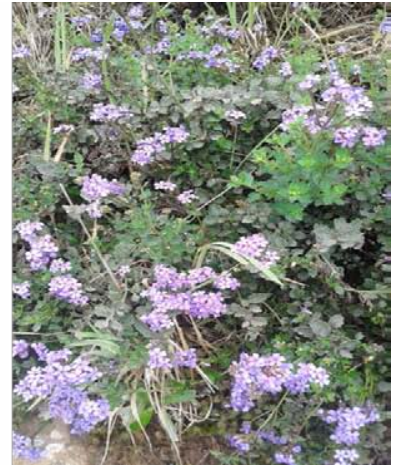

FULL BLOOM

Figure 5. Percentage (\%) of individuals in the vegetative and reproductive phenophases of Verbena rigida in Serra do Oratório, from August 2016 to July 2017.

Source: author (2017). 
In early summer, when it forms showy tufts that stand out in the landscape, $100 \%$ of the individuals were in full bloom. The dormancy of the species was inversely proportional to temperature (maximum, minimum and average) and precipitation. Phenophases foliage, flower buds and full bloom showed an equally proportional correlation with climate variables average, maximum and minimum temperature (Table 7).

Table 7. Spearman correlations (rs) between Verbena rigida phenophases and environmental variables in Serra do Oratório, from August 2016 to July 2017. Correlation coefficients in bold are significant $(p \leq 0.05)$.

\begin{tabular}{|c|c|c|c|c|c|}
\hline \multirow{2}{*}{ Phenophase } & $\begin{array}{c}\text { Average } \\
\text { temperature }\end{array}$ & $\begin{array}{c}\text { Max } \\
\text { temperature }\end{array}$ & $\begin{array}{c}\text { Min } \\
\text { temperature }\end{array}$ & Precipitation & Insolation \\
\hline & $\left({ }^{\circ} \mathrm{C}\right)$ & $\left({ }^{\circ} \mathrm{C}\right)$ & $\left({ }^{\circ} \mathrm{C}\right)$ & $(\mathrm{mm})$ & (h) \\
\hline \multirow{2}{*}{ Dormancy } & $-0.585^{*}$ & -0.53 & -0.753 & -0.53 & -0.0279 \\
\hline & $<.0001^{* *}$ & $<.0001$ & $<.0001$ & $<.0001$ & ns \\
\hline \multirow{2}{*}{ Leaves } & 0.585 & 0.53 & 0.753 & 0.53 & 0.0279 \\
\hline & $<.0001$ & $<.0001$ & $<.0001$ & $<.0001$ & ns \\
\hline \multirow{2}{*}{ Flower bud } & 0.324 & 0.324 & 0.259 & 0 & 0.453 \\
\hline & 0.0118 & 0.0118 & 0.0457 & ns & 0.0003 \\
\hline \multirow{2}{*}{ Bloom } & 0.7 & 0.7 & 0.7 & -0.195 & 0.355 \\
\hline & $<.0001$ & $<.0001$ & $<.0001$ & ns & 0.0059 \\
\hline \multirow{2}{*}{ Fruit set } & 0.0526 & -0.0376 & 0.143 & 0.0526 & -0.233 \\
\hline & ns & ns & ns & ns & ns \\
\hline \multirow{2}{*}{ Ripeness } & -0.113 & -0.209 & -0.0161 & 0.451 & -0.483 \\
\hline & ns & ns & ns & 0.0003 & 0.0001 \\
\hline
\end{tabular}

Source: author (2017)

*correlation coefficient; **significance level ( $\mathrm{p}$ value); ns = non-significant.

The appearance of flower buds and full bloom are positively correlated with heat stroke. The vegetative stage and ripening of Verbena rigida fruits can be correlated with precipitation (Table 7). In May, when there is a fall in the hours of sunshine (Figure 6), fruit ripening occurs in 100\% of the evaluated individuals, thus presenting a negative correlation (Table 7). 

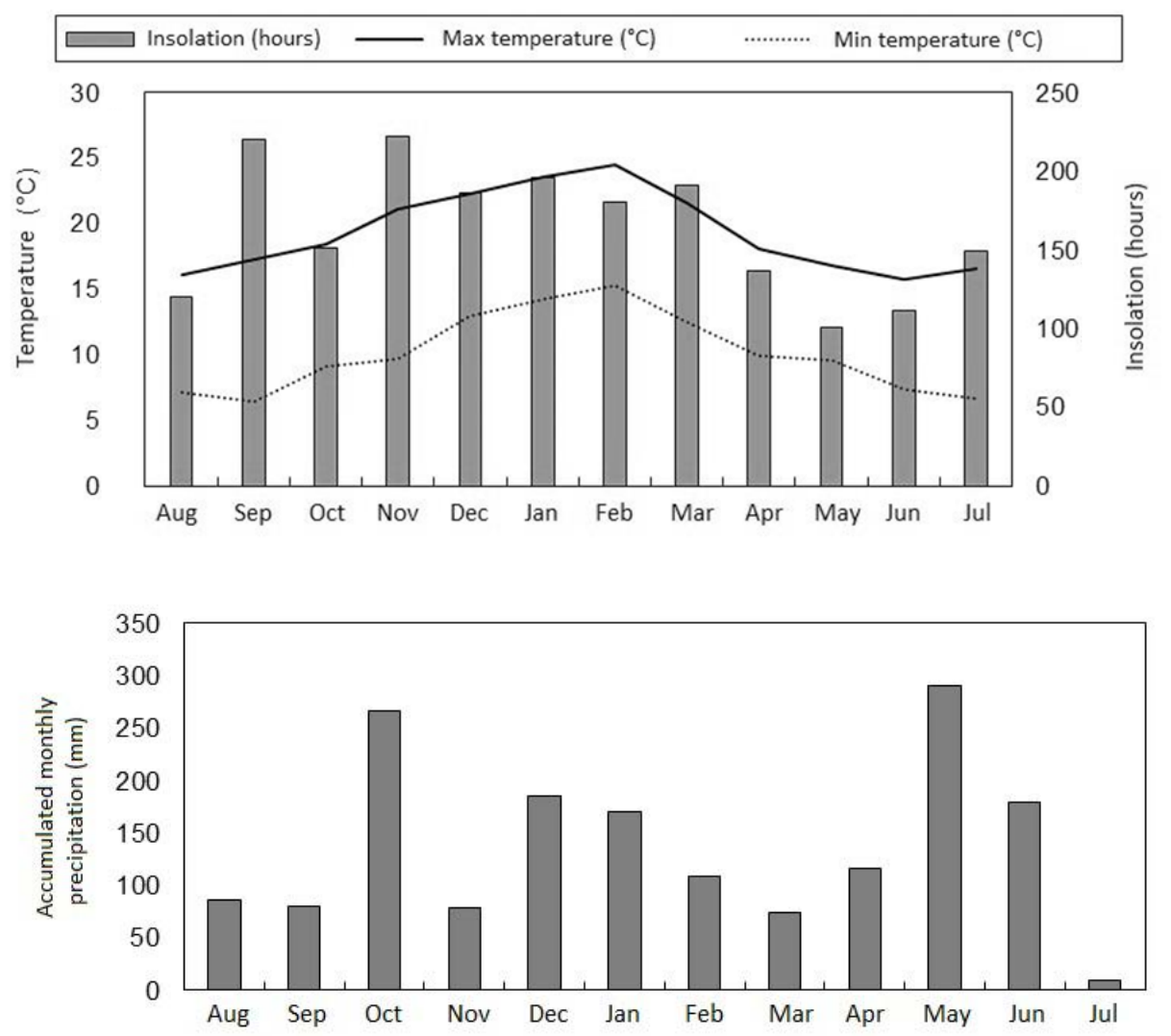

Figure 6. Distribution of insolation and temperature (A) and precipitation distribution (B) between August 2016 and July 2017.

Source: EPAGRI/CIRAM (2017)

Poorly tolerant to shading, so their stems grow for brightness, but coexists well with overgrown grass species (Livramento and Zoldan, 2011). Verbena rigida, during the year, has its reproductive period interrupted in winter, moving to the vegetative period. During the months of June and July it was found in the vegetative period (Biondi et al., 2007).

Its geographical distribution occurs in the three states of the southern region of the country (Paraná, Santa Catarina and Rio Grande do Sul) and in the southeast region of the states of Minas Gerais and São Paulo (O’Leary, 2017).

In landscaping its potential use can be in filling beds as a creeping plant and can replace creeping exotic plants. Verbena rigida is a very vigorous species, with its easily rooted rhizomes spreading along the roadside through rocks. At the end of winter, when its shoots look dry and appear to be dead, underneath other nearby plants, small buds can be seen emerging.

Examined material: BRASIL. SANTA CATARINA: Bom Jardim da Serra, September $28^{\text {th }} 2017$, F.E.A.Bastos 9020 (LUSC).

In general, the species have short flowering and fruiting periods, none lasting more than 3 months. From June to October no species had reproductive structures, characterized only by having a vegetative part or absence of it, characterizing dormancy period (Table 2). Regarding the phenology of the studied species, with the exception of Trichocline catharinensis, all presented dry or nonexistent aerial part in September of the year studied. This information may be associated with pasture burnings during this period, where the species studied is completely surrounded by pasture. Mantovani et al. (2003), affirm that the reproductive period is an important phase for the population dynamics and for the species survival itself. Due to the fact that the species were evaluated for a period of 12 months, at least one more year of evaluation in this area would be necessary to confirm the behavior of the species in the Serra do Oratório.

The study site is characterized by being an environment with extreme abiotic factors, which can probably lead to a short flowering and fruiting period of the studied species. Regarding the climate data collected, precipitation has its lowest point in July, August and September (Figure 6). The temperature has the lowest point between the April-MayJune quarters and the highest point in January-FebruaryMarch for temperature (Figure 6). The results found by Biondi et al. (2007) corroborate the results found in the present work, obtaining the same points in the compared months. Between July and September, when precipitation values reach their lowest point on the chart, most species are not in the flowering and fruiting period. The highest temperature points, on the other hand, showed higher relationships with leaf budding, flowering and fruiting phenophases for most species (Biondi et al., 2007). 
Of the perennial species, many rest in the dry season and complete a new annual growing season in the following rainy season. The occurrence of droughts can also change plant phenology in humid regions. In general, water deficit reduces plant growth and causes fall of leaves, flowers and fruits (Bergamaschi, 2007). This statement may explain the fact that the species studied, with the exception of Trichocline catharinensis, presented their dry and/or leafless shoots in September, when there was low precipitation, and according to studies with these species, this situation It is not commonly observed. The regional climate does not have the same characteristics annually, so it is necessary to perform an analysis of climate records and consequently a better interpretation of their effects (Francisco et al., 2016).

Flowering of the species occurred in the same period identified in the field, during the phenological evaluations. From these characteristics it can be inferred that the species studied, besides having ornamental potential, can be promising regarding the permanence of their shoots throughout the year in places where the climate is less rigid, such as in a greenhouse. In addition, these species can be used for breeding programs, making features such as corolla color an attractive feature for future improvement, as well as being native species and preserving the regional identity of the local flora.

Selected ornamental plants have particular attributes that should be considered in the pursuit of the potential use of each species, and the rational use of native plant species can be an efficient mechanism for enhancing and conserving biodiversity (Siminski and Reis, 2011). Among the species studied, only Verbena rigida is not endemic to Brazil, according to Iganci et al. (2011). The vegetation found in the higher regions of southern Brazil shares both typically tropical and temperate lineages, which are distributed across fields and forests and concentrate most of the species unique to southern Brazilian flora.

Regarding soil factors, it was observed in the field that the species Baccharis nummularia, Tibouchina dubia, Trichocline catharinensis and Calibrachoa sellowiana occurred in areas where the soil is very peaty, with high levels of organic matter (Table 8).

Table 8. Simplified soil analysis for the species C. sellowiana, B. nummularia, T. dubia, V. rigida and T. catharinensis, in Serra do Oratório, Bom Jardim da Serra (SC).

\begin{tabular}{|c|c|c|c|c|c|c|c|c|c|}
\hline Species & $\mathrm{Ph}_{2} \mathbf{0}$ & O.M. & $\mathrm{Ca}$ & Mg & Al & $\mathbf{N a}$ & $\mathbf{K}$ & $\mathbf{H}+\mathbf{A l}$ & CTC efet. \\
\hline & $(1: 1)$ & $\%$ & $\begin{array}{c}\text { Cmolc/ } \\
\mathbf{d m}^{3}\end{array}$ & $\begin{array}{c}\text { Cmolc/ } \\
\mathbf{d m}^{3}\end{array}$ & $\begin{array}{c}\text { Cmolc/ } \\
\mathbf{d m}^{3}\end{array}$ & $\mathrm{Mg} / \mathrm{dm}^{3}$ & $\mathbf{M g} / \mathbf{d m}^{3}$ & $\begin{array}{c}\text { Cmolc/ } \\
\mathbf{d m}^{3}\end{array}$ & Cmolc/dm ${ }^{3}$ \\
\hline C. sellowiana & 4.8 & 12.1 & 1.72 & 0.86 & 1.2 & 1.0 & 107 & 38.6 & 4.05 \\
\hline B. nummularia & 4.9 & 12.2 & 0.54 & 0.85 & 0.93 & 1.0 & 219 & 43.3 & 2.88 \\
\hline T. dubia & 5.2 & 12.2 & 0.61 & 0.58 & 0.53 & 1.0 & 132 & 24.4 & 2.06 \\
\hline V. rigida & 5.2 & 4.1 & 3.02 & 1.22 & 0.39 & 1.0 & 109 & 15.4 & 4.91 \\
\hline T.catharinensis & 4.6 & 15.2 & 0.25 & 0.43 & 1.16 & 1.0 & 108 & 48.6 & 2.12 \\
\hline
\end{tabular}

Source: Laboratory of Soil Analysis - LAS - CAV/UDESC. 2017.

The presence of significant organic horizon around these species, formed by material from accumulated grass cutting, provided conditions for these plants to develop (Leal and Biondi, 2006). Already Verbena rigida was present in places where there was visible anthropic interference (roadsides and paths), and as studies by Leal and Biondi (2006) state, also with native plants with ornamental potential, these anthropized sites are characterized by not presenting the horizon. surface and/or other altered horizons (consequently a physicochemical decharacterization) and presence of erosive grooves. Thus, these species have great potential for planting in landscape projects in degraded or disturbed areas of similar situation. The studied species may also compose future landscape projects in areas that need to be viable, economically and sustainably recovered.

\section{Conclusions}

Trichocline catharinensis can be a promising species for landscaping, because even during winter, it keeps its aerial part showy, covering the substrate. The species Tibouchina dubia, Verbena rigida and Calibrachoa sellowiana, even with short flowering time, are indicated for use in landscaping in the region of Santa Catarina Plateau. The meteorological variables evaluated presented correlations with the phenophases of the studied species. Baccharis nummularia has an extensive vegetative period, which becomes an interesting species for landscaping throughout the year. 


\section{Author Contribution}

FEAB: contributed to the design and execution of field experiments, data tabulation, graphs and tables, statistics, and writing; FG: contributed to data tabulation, writing and translation of the article into English.

\section{Acknowledgments}

We thank Herbarium LUSC and CAPES for its financial support.

\section{References}

BACKES, P.; IRGANG, B. Mata Atlântica: as árvores e a paisagem. Porto Alegre: Editores Paisagem do Sul, 2004. $396 \mathrm{p}$.

BADECK, F.W.; BONDEAU, A.; BÖTTCHER, K.; DOKTOR, D.; LUCHT, W.; SCHABER, J.; SITCH, S. Responses of spring phenology to climate change. New Phytologist, v.162, p.295-309, 2004.

BARROSO, G.M.; BUENO, O.L. Compostas, subtribo Baccharidinae. In: REITZ, R. Flora Ilustrada Catarinense. Itajaí: Herbário Barbosa Rodrigues, 2002. p.777-784.

BERGAMASCHI, H. O clima como fator determinante da fenologia das plantas. In: REGO, G.M.; NEGRELLE, R.R.B.; MORELLATO, L.P.C. (ed.). Fenologia: ferramenta para conservação, melhoramento e manejo de recursos vegetais arbóreos. Colombo: Embrapa Florestas, 2007. p.290-310.

BIONDI, D. Paisagismo. Recife: Imprensa Universitária da UFRPE, 1990. 184p.

BIONDI, D.; LEAL, L.; BATISTA, A.C. Fenologia do florescimento e frutificação de espécies nativas dos Campos. Acta Scientiarum. Biological Sciences, v.29, n.3, p.269-276, 2007.

BRASIL, MMA. Relatório Metodológico do Mapeamento de Uso do Solo e Vegetação Natural para a proposta de criação de Corredor Ecológico/Unidade de Conservação no Rio Pelotas e Campos de Cima da Serra. Brasília: Ministério do Meio Ambiente, 2007.

CABRERA, Á.L.; KLEIN, R.M. Compostas, Tribo Mutiseae. In: REITZ, R. Flora Ilustrada Catarinense. Herbario Barbosa Rodrigues, v.1, 1973. p.1-124.

CHAMAS, C.C.; MATTHES, L.A.F. Método para levantamento de espécies nativas com potencial ornamental. Ornamental Horticulture, v.6, n.1, p.53-63, 2000.
CIRAM. 2002. Atlas Climatológico do Estado de Santa Catarina. Available at: <http://www.ciram.epagri.sc.gov. br/index.php?option $=$ com_content $\&$ view $=$ article\&id $=708$ $\&$ Itemid $=484>$ Accessed on: August $17^{\text {th }} 2020$.

CORADIN, L.; SIMINSKI, A.; REIS, A. Espécies nativas da flora brasileira de valor econômico atual ou potencial. Brasília: Ministério do Meio Ambiente, 2011. 696p.

EMBRAPA. Mapa Convenção cartográfica: escala 1:250.000. Rio de Janeiro: EMBRAPA, 1998. 2p.

EPAGRI. Dados e informações biofísicas da unidade de planejamento regional planalto sul catarinense - UPR3. Florianópolis: Epagri, 2002. 76.

FALKENBERG, D.; VOLTOLINI, J.C. The montane cloud forest in southern Brazil. In: Tropical Montane cloud forests. New York: Springer, 1995. p.138-149.

FILGUEIRAS, T.D.S.; NOGUEIRA, P.E.; BROCHADO, A.L.; GUALA, G.F. Caminhamento: um método expedito para levantamentos florísticos qualitativos. Cadernos de Geociências, v.12, n.1, p.39-43, 1994.

FRANCISCO, P.R.M.; PEDROZA, J.P.; BANDEIRA, M.M.; DA SILVA, L.L.; SANTOS, D. Mapeamento da insolação do estado da paraíba utilizando Krigeagem. Revista de Geografia. v.33, n.1, p.248-262, 2016.

GUIMARÃES, P.J.F. 2016. Tibouchina In: Lista de Espécies da Flora do Brasil. Jardim Botânico do Rio de Janeiro. Available at: <http://floradobrasil.jbrj.gov.br/jabot/ floradobrasil/FB9904>. Accessed on: Mai 13th 2016.

IBGE. Manual técnico da vegetação brasileira. Rio de Janeiro: Fundação Instituto Brasileiro de Geografia e Estatística, 2012. 271p.

IGANCI, J.R.; HEIDEN, G.; MIOTTO, S.T.S.; PENNINGTON, R. Campos de Cima da Serra: the Brazilian Subtropical Highland Grasslands show an unexpected level of plant endemism. Botanical Journal of the Linnean Society, v.167, n.4, p.378-393, 2011.

LIRA FILHO, J.A.; PAIVA, H.N.; GONÇALVES, W.; VIEIRA, E.D.A. Paisagismo: elementos de composição e estética. Viçosa: Aprenda Fácil, 2002. 173p.

KANAYA, T.; KOKUBUN, H.; WATANABE, H.; HASHIMOTO, G.; MARCHESI, E.; BULLRICH, L.; ANDO, T. Flowering ability of commercial Calibrachoa cultivars as compared to that of natural species. Scientia Horticulturae, v.126, n.2, p.276-283, 2010.

LEAL, L.; BIONDI, D. Potencial ornamental de espécies nativas. Revista Científica Eletrônica de Engenharia Florestal, v.4, n.8, p.1-16, 2006. 
LEITE, P.F. Contribuição ao conhecimento fitoecológico do sul do Brasil. Ciência e Ambiente, v.24, p.51-73, 2002.

LIVRAMENTO, G. Trichocline catharinensis: cravocomum. In: CORADIN, L.; SIMINSKI, A.; REIS, A. Espécies nativas da flora brasileira de valor econômico atual ou potencial: plantas para o futuro- Região Sul. Brasília: MMA, 2011. p.824- 828.

LIVRAMENTO, G.; ZOLDAN, S.R. Verbena rigida: verbena-comum. In: CORADIN, L.; SIMINSKI, A.; REIS, A. Espécies nativas da flora brasileira de valor econômico atual ou potencial: plantas para o futuroRegião Sul. Brasília: MMA, 2011. p.829- 833.

LONGHI-WAGNER, H.M. Diversidade florística dos campos sul-brasileiros: Poaceae. In: JARDIM, M.A.G.; BASTOS, M.N.C.; SANTOS, J.U.M. Desafios da Botânica no Novo Milênio: Inventário, Sistematização e Conservação da Diversidade Vegetal. Belém: Sociedade Botânica do Brasil, 2003. p.117-120.

LORENZI, H.; SOUZA, H. M. Plantas Ornamentais do Brasil: arbustivas, herbáceas e trepadeiras, 3ed. Nova Odessa: Plantarum, 2001. 558p.

MANTOVANI, M.; RUSCHEL, A.R.; REIS, M.D.; PUCHALSKI, A.; NODARI, R.O. Fenologia reprodutiva de espécies arbóreas em uma formatação secundária da floresta atlântica. Revista Árvore, v.27, n.14, p.451-458, 2003.

MARTINI, A.; BIONDI, D.; BATISTA, A.C.; NATAL, C.M. Fenologia de espécies nativas com potencial paisagístico. Semina: Ciências Agrárias, v.31, n.1, p.7584, 2010.

NEWSTROM, L.E.; FRANKIE GORDON, W.; BAKER, H.G. A new classification for plant phenology based on flowering patterns in lowland tropical rain forest trees at $\mathrm{La}$ Selva, Costa Rica. Biotropica, p.141-159, 1994.
O'LEARY, N. Verbena in Flora do Brasil 2020 em construção. Jardim Botânico do Rio de Janeiro. Available at: <http://floradobrasil.jbrj.gov.br/reflora/floradobrasil/ FB15214>. Accessed on: Aug. $4^{\text {th }} 2017$.

PROBIO (Projeto de conservação e utilização sustentável da diversidade biológica Brasileira). Áreas prioritárias para a conservação, utilização sustentável e repartição de benefícios da biodiversidade brasileira. Projeto de conservação e utilização sustentável da diversidade biológica brasileira. Brasília: Editora MMA/SBF, 2003.

REITZ, R. Plano de coleção. In: REITZ, R. Flora Ilustrada Catarinense. Itajaí: Herbário Barbosa Rodrigues, 1965. p.1-70.

RODERJAN, C.V.; GALVÃO, F.; KUNIYOSHI, Y.S.; HATSCHBACH, G.G. As unidades fitogeográficas do Estado do Paraná. Ciência and Ambiente, v.24, p.75-92, 2002.

SCHWARTZ, M.D. Advancing to full bloom: planning phenological research for the 21 st century. International Journal of Biometeorology, v.42, n.3, p.113-118, 1999.

SIMINSKI, A.; REIS, A. Espécies ornamentais nativas da região Sul do Brasil. Espécies nativas da flora brasileira de valor econômico atual ou potencial-plantas para o futuro-Região Sul, Brasília: Ministério do Meio Ambiente, 2011. 934p.

TOGNON, G.B.; CUQUEL, F.L. Potencial ornamental de Baccharis milleflora e Baccharis tridentatacomo folhagem de corte. Ciência Rural, v.46, n.1, p.70-75, 2016.

VAN DEN BERG, A.E. From green space to green prescriptions: challenges and opportunities for research and practice. Frontiers in Psychology, v.8, n.268, p.1-4, 2017. DOI: https://doi.org/10.3389/fpsyg.2017.00268 